\title{
Hubungan Kecepatan Lari Dan Daya Ledak Otot Tungkai Dengan Hasil Kemampuan Lompat Jauh Gaya Jongkok
}

\section{The Relationship between Running Speed and Explosive Power of Leg Muscles with the Results of the Long Jump Ability Squatting}

Rahmad Firdaus ${ }^{1)}$ Anton Kurnia Hadisaputro ${ }^{2)}$

SD Negeri 12 Pelerang ${ }^{1)}$, SMA Negeri 1 Siantan ${ }^{2)}$

Email: firdausrahmad.rf@gmail.com ${ }^{1)}$, anton.kurnia82@gmail.com ${ }^{2)}$

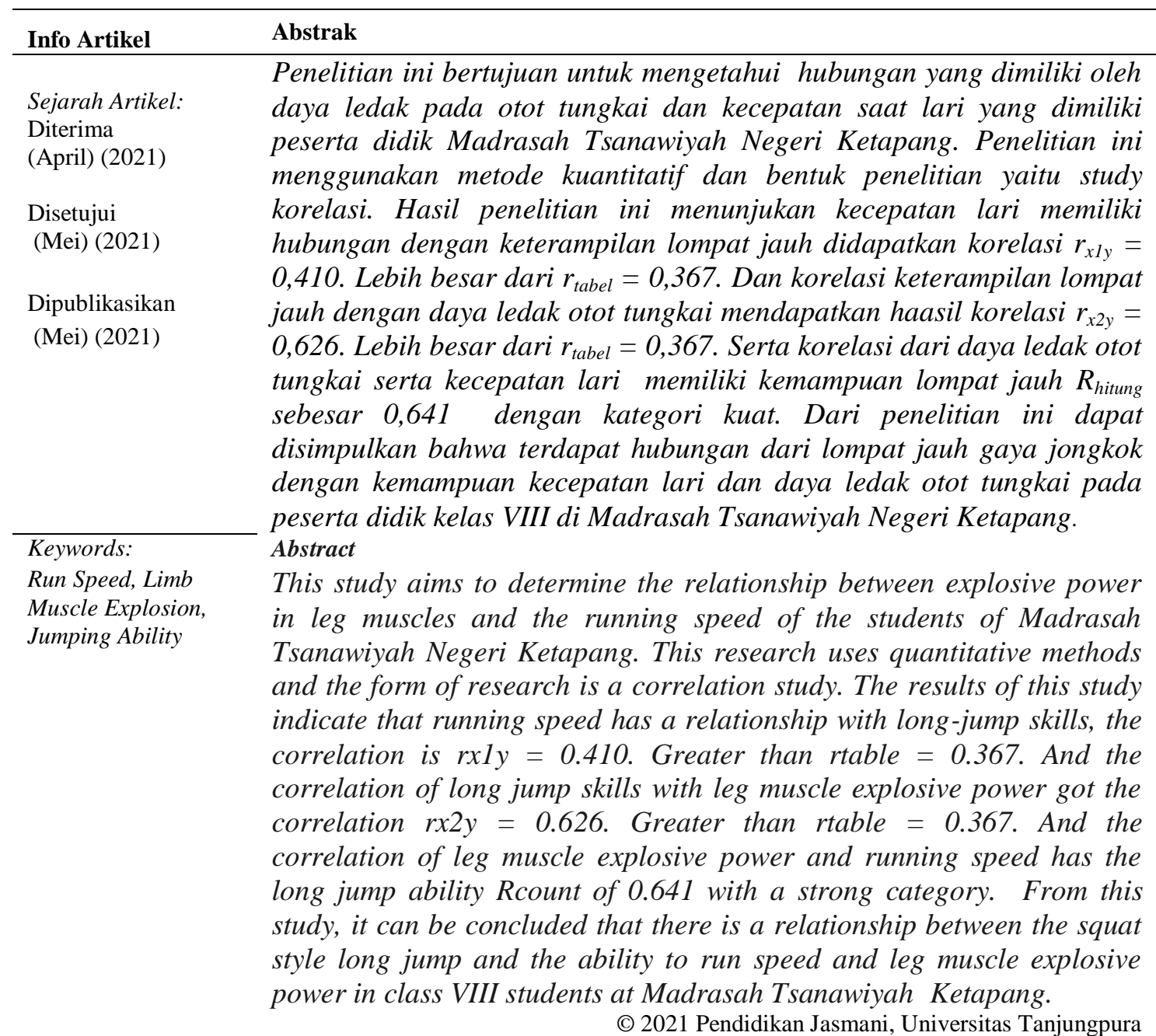

Alamat korespondensi

E-mail

No Handphone
Jl. Bayangkara Kolmplek Vila Anugrah a41 Sukadana,

firdausrahmad.rf@gmail.com 


\section{PENDAHULUAN}

Dalam dunia pendidikan jasmani, oahraga dan kesehatan dapat diketahui diketahui bahwa telah dikenal dan dilakukan sampai pada tahap yang mana sudah menyentuh semua kalangan, mulai dari kurikulum pendidikan dasar hingga pendidikan pada perguruan tinggi memiliki mata pelajaran/kuliah penjaskes. Saat ini penjaskes telah menjadi bagian integral yang pada keseluruhan tujuan utamanya pendidikan secara umum. Yang berguna untuk meningkatkan keterampilan gerak dalam tubuh, kebugaran jasmani, memiliki stabilitas emosional, dapat berfikir kritis dalam menanggapi sesuatu, memiliki penalaran dan tindakan moral yang baik dengan sistematis dengan jasmani. Hal ini tentu salah satu bentuk sistem pendidikan Indonesia (Widiyatmoko, 2017)

Salah satu cabang olahraga atletik cukup dikenal dunia. Aktifitas jasmani atletik dilaksanakan secara kompetitif. Dalam hal ini dapat di jabarkan dengan nomor yang tidak menyatu yaitu berlari, melempar, melompat, juga pada gerak berjalan. Kemudian dari semua cabang olahraga diketahui cabang atletik merupakan induknya dan tertua cabang olahraga. (Sobarna, 2020)

Penjelasan tentang materi lompat dilihat dalam tehnik tidak banyak berubah, bahkan pada masa-masa yang lalu, tehnik jongkok murni telah diterapkan berbagai pendapat (versi seseorang), tentang lompatan. Persaratan seperti gerak yang luwes (bebas), terutama pada waktu melayang dan kecepatan awal saat melayang diudara dan persiapkan pula pendaratan yang baik. Mendapatkan hasil lompatan sejauh mungkin merupakan suatu tujuan lompat jauh dengan berapa fase tertentu yang dilakukan untuk mencapai jarak (Arifah, 2014). Dengan begitu, untuk mendapatkan hasil lompatan jauh, atlet harus memahami/ mengetahui bahwa teknik melompat jauh memiliki unsurunsur pokok dalam melakukan lomat juah tersebut menurut (Aziz, 2018) Agar atlet mampu memperoleh lompatan sejauh mungkin, hal tersebut memiliki faktor, yaitu faktor-faktor tersebut memiliki 7 faktor, pertama, harus memiliki daya tahan tubuh yang baik, panjang tungkai dan kekuatan otot tungkai yang dimiliki serta memiliki kecepatan dalam berlari saat mengambil awalan, memiliki teknik lompatan yang benar, teknik melayang diudara, dan pendaratan yang sempurna.

Adapun suatu usaha untuk mencapai tujuan yang ingin meningkatkan kemampuan dalam pendidikan jasmani diperlukan hasil belajar diluar juga didalam kelas (lapangan), dalam hal ini untuk meningkatkan suatu kemampuan dalam lompat jauh, salah satunya dengan melakukan peregangan otototot sebelum masuk kemateri inti dalam penjaskes, sehingga tubuh menjadi siap untuk melakukan segala aktivitas yang ada hubungannya dengan hasil belajar (Nur, 2019). Dengan beberapa pengembangan yang merupakan program pengajaran ciri khas, yang bermaksud untuk memberikan tambahan pengetahuan dan keterampilan siswa dalam rangka mencapai tujuan pendidikan, melalui pengembangan secara emosi dan spritual yang dimiliki siswa. Program ini mencakup mata pelajaran pendidikan jasmani yang menggarah pada peningkatan penguasaan teknik olahraga.

Kendala yang didapatkan oleh guru penjaskes saat proses pelaksanaan lompat jauh berlangsung. Setiap peserta didik memiliki kemampuan yang berbeda, khususnya teknik lompat jauh gaya jongkok dengan menggunakan kecepatan dan punggung kaki. Peneliti mencoba mengangkat sebuah permasalahan yang berkaitan dengan kemampuan lompat jauh dalam cabang olahraga atletik salah satunya di Madrasah Tsanawiyah Negeri Ketapang.

Berdasarkan pada proses pembelajaran pendidikan jasmani yang dilaksanakan pada siswa Madrasah Tsanawiyah Negeri Ketapang menurut pengamatan memberikan gambaran nyata bahwa para siswa lompatanya jauh masih belum mencukupi ini dapat dilihat ketika pada saat pengambilan nilai ahir ketika melakukan lompat jauh masih dibawah KKM. Pada hal siswa pada umumnya memiliki otot kaki yang kuat, kecepatan lari, dan memiliki ancang-ancang yang baik pula saat ingin melakukan lompatan, disamping teknik-teknik lompat jauh itu sendiri.

Dari hasil pengamatan kenyataan dan kondisi yang dimiliki serta kemampuan penampilan siswa ketika melakukan lompat jauh, maka muncul ide meneliti tentang daya pada ledak tungkai dan kecepatan hasil lari, yang dihubungkan ke kemampuan lompatan itu sendiri. Jadi untuk menjawab hal tersebut, 
munculah ide peneliti untuk mengambil judul "Hubungan Kecepatan Lari dan Daya Ledak Otot Tungkai Dengan Hasil Kemampuan Lompat Jauh Gaya Jongkok Pada Siswa Putra Kelas VIII Madrasah Tsanawiyah Negeri Ketapang".

\section{METODE PENELITIAN}

Metode dalam penelitian ini adalah metode kuantitatif dengan bentuk korelasi. Serta Corelation studies guna mengetahui apakah hubungan antara 2 variabel atau lebih

1. $\mathrm{X}_{1}$ dan $\mathrm{Y}$ : tersebut memiliki hubungan (Suharsimi Arikunto (2010:207).

\section{HASIL DAN PEMBAHASAN}

\section{Hubungan variabel terikat dan variabel bebas}

Hasil dari hubungan 2 variabel bebas sebagai berikut daya ledak pada otot tungkai dan kecepatan saat lari dengan variabel terikat terhadap kemampuan lompat jauh pada peserta didik Madrasah Tsanawiyah Negeri Ketapang, didapatkan hasil, yaitu :

Tabel 1 Statistik Deskriptif

\begin{tabular}{llll}
\hline & \multicolumn{1}{c}{ N } & \multicolumn{1}{c}{ Mean } & Std. Deviation \\
\hline Hasil Hitung Kecepatan Lari $\left(\mathrm{X}_{1}\right)$ & 29 & 42,03 & 3,365 \\
\hline Hasil Lompat Jauh $(\mathrm{Y})$ & 29 & 3,3138 &, 58258 \\
\hline Valid N (Listwise) & 29 & Mean & Std. Deviation \\
\hline
\end{tabular}

Tabel 2 Korelasi

\begin{tabular}{|c|c|c|}
\hline & & $\begin{array}{l}\text { Hitung Kecepatan Hasil Lompat } \\
\text { Lari }\left(X_{1}\right)\end{array}$ \\
\hline Hasil Hitung & Pearson Correlation &, $410^{\prime \prime}$ \\
\hline Kecepatan Lari & Sig. (2-Tailed) &, 027 \\
\hline$\left(\mathrm{X}_{1}\right)$ & $\mathrm{N}$ & 29 \\
\hline & Pearson Correlation &, $410^{*}$ \\
\hline $\begin{array}{l}\text { Hasil Lompat } \\
\text { Jauh (Y) }\end{array}$ & Sig. (2-Tailed) & ,027 \\
\hline & $\mathrm{N}$ & 29 \\
\hline $\begin{array}{l}\text { Berdasark: } \\
\text { dengan rumus t } \\
\text { sebesar } 0,410 \text { den } \\
\text { Tingkat signifikan }\end{array}$ & $\begin{array}{l}\text { In hasil pengolahan data } \\
\text { ersebut, diperoleh hasil } \\
\text { gan kategori cukup kuat. } \\
\text { i hasil lebih kecil yaitu: } \alpha\end{array}$ & $\begin{array}{l}=0,05 \text { atau }(0,027<0,05) \text { dari dua } \\
0,027 \text { pada hasil nilai p-va } \\
\text { Kemudian dari pada itu menolak } \\
\text { kata lain memiliki hubungan. }\end{array}$ \\
\hline & Tabel 3 & si Nilai R \\
\hline & Tingkat Hubungan & Koefisien Interval \\
\hline & $\begin{array}{c}\text { Sangat Erat } \\
\text { Erat } \\
\text { Cukup Erat } \\
\text { Kurang } \\
\text { Sangat Kurang }\end{array}$ & $\begin{array}{l}0.80-1.000 \\
0.60-0.799 \\
0.40-0.599 \\
0.20-0.399 \\
0,00-0.199\end{array}$ \\
\hline
\end{tabular}

\section{2. $X_{2}$ dan $Y$ : Koefisien Korelasi Sederhana}

Tabel 4 Statistik Deskriptif

\begin{tabular}{llcc}
\hline & N & Mean & Std. Deviation \\
\hline Power otot tungkai $\left(\mathrm{X}_{2}\right)$ & 29 & 1,9266 &, 24097 \\
\hline Hasil lompat jauh $(\mathrm{Y})$ & 29 & 3,3138 &, 58258 \\
\hline Valid N (listwise) & 29 & & \\
\hline
\end{tabular}


Tabel 5 Correlations

\begin{tabular}{|c|c|c|c|}
\hline & & $\begin{array}{c}\text { Power otot tungkai } \\
\left(\mathrm{X}_{2}\right)\end{array}$ & $\begin{array}{c}\text { hasil lompat jauh } \\
\text { (Y) }\end{array}$ \\
\hline \multirow{3}{*}{ Kekuatan Otot Tungkai $\left(\mathrm{X}_{2}\right)$} & Pearson Correlation & 1 &, $626^{* *}$ \\
\hline & Sig. (2-Tailed) & &, 000 \\
\hline & $\mathrm{N}$ & 29 & 29 \\
\hline \multirow{3}{*}{ Hasil Lompat Jauh (Y) } & Pearson Correlation & $626^{* *}$ & 1 \\
\hline & Sig. (2-Tailed) &, 000 & \\
\hline & $\mathrm{N}$ & 29 & 29 \\
\hline
\end{tabular}

Berdasarkan hasil pengolahan data dengan rumus tersebut, diperoleh hasil sebesar 0,626 dengan kategori kuat. Tingkat signifikansi memiliki hasil lebih kecil $\alpha=$ 0,05 atau
$(0,00<0,05)$ dari dua sisi adalah 0,000 pada hasil nilai p-value (+/-). Kemudian dari pada itu menolak $H_{0}$ dengan kata lain memiliki hubungan.

Tabel 6 Hubungan Nilai R

\begin{tabular}{cc}
\hline Tingkat Hubungan & Koefisien Interval \\
\hline Sangat Kuat & $0.80-1.000$ \\
Kuat & $0.60-0.799$ \\
Cukup Kuat & $0.40-0.599$ \\
Kurang & $0.20-0.399$ \\
Sangat Kurang & $0,00-0.199$ \\
\hline
\end{tabular}

3. $X_{1} X_{2}$ dan $Y$

Tabel 7 Statistik Deskriptif

\begin{tabular}{lccc}
\hline & N & Mean & Std. Deviation \\
\hline Hasil Hitung Kecepatan Lari $\left(\mathrm{X}_{1}\right)$ & 29 & 42,03 & 3,365 \\
\hline Power Otot Tungkai $\left(\mathrm{X}_{2}\right)$ & 29 & 1,9266 &, 24097 \\
\hline Valid N (Listwise) & 29 & & \\
\hline
\end{tabular}

Tabel 8 Correlations

\begin{tabular}{lccc}
\hline & & $\begin{array}{c}\text { Hasil Hitung } \\
\text { Kecepatan Lari } \\
\left(\mathbf{X}_{\mathbf{1}}\right)\end{array}$ & $\begin{array}{c}\text { Power Otot } \\
\text { Tungkai }\left(\mathbf{X}_{\mathbf{2}}\right)\end{array}$ \\
\hline Hasil Hitung Kecepatan & Pearson Correlation & 1 &, $429^{*}$ \\
\cline { 2 - 4 } Lari $\left(\mathbf{X}_{\mathbf{1}}\right)$ & Sig. (2-Tailed) & 29 &, 020 \\
\hline \multirow{2}{*}{ Power Otot Tungkai $\left(\mathbf{X}_{\mathbf{2}}\right)$} & $\mathrm{N}$ &, $429^{*}$ & \multicolumn{1}{c}{1} \\
\cline { 2 - 4 } & Pearson Correlation &, 020 & 29 \\
\cline { 2 - 4 } & Sig. (2-Tailed) & 29 & 29 \\
\hline
\end{tabular}

Berdasarkan hasil pengolahan data dengan rumus tersebut, diperoleh hasil sebesar 0,429 dengan kategori kuat. Tingkat signifikansi memiliki hasil yang lebih kecil yaitu: $\alpha=$
0,05 atau $(0,02,<0,05)$ dari dua sisi adalah 0,020 pada hasil nilai p-value (+/-). Kemudian dari pada itu menolak $H_{0}$ dengan kata lain memiliki hubungan. 
Tabe 9 Variabel Terikat Dan Variabel Bebas

\begin{tabular}{cccc}
\hline Variabel & $\mathbf{R}_{\text {hitung }}$ & $\mathbf{R}_{\text {tabel }} \mathbf{5 \%}$ & Tingkat Signifikasi \\
\hline $\mathrm{X}_{1} \mathrm{y}$ & 0,410 & 0,367 & Ada Hubungan \\
\hline $\mathrm{X}_{2} \mathrm{y}$ & 0,626 & 0,367 & Ada Hubungan \\
\hline $\mathrm{X}_{1} \mathrm{x}_{2}$ & 0,429 & 0,367 & Ada Hubungan \\
\hline
\end{tabular}

Information:

$\mathrm{X}_{1} \quad=$ Kecepatan Lari

$\mathrm{X}_{2} \quad=$ Power Otot Tungkai

$\mathrm{r}_{\text {hitung }}=$ Perhitungan Nilai Variabel bebas dan terikat

rt $\quad=$ Nilai Tabel Product Momen

a. Hubungan kecepatan lari $\left(\mathrm{X}_{1}\right)$ dan lompat jauh (Y) hasi yang diperoleh $r_{x 1 y}=0,410$. Signifikasi $r_{\text {tabel }}=0,367$ yaitu memiliki hasil signifikan 5\%, didapat bahwa hipotesis nihil (Ho) tidak diterima sedangkan hipotesis alternatif (Ha) diterima. Dapat diketahui terdapat hubungan kecepatan lari $\left(\mathrm{X}_{1}\right)$ dan kemampuan lompat jauh (Y).

Berdasarkan hasil pengolahan data dengan rumus tersebut, diperoleh hasil sebesar 0,641 b. Daya ledak otot tungkai $\left(\mathrm{X}_{2}\right)$ dan kemampuan lompat jauh (Y) terdapat hubungan $r_{x 2 y}=0,626$ dengan $r_{\text {tabel }}=$ 0,00 hasil hubungan $5 \%$, dalam hal ini hipotesis alternatif (Ha) di accept, sedangkan hipotesis nihil (Ho) tidak diterima. Terdapat hubungan daya ledak otot tungkai $\left(\mathrm{X}_{2}\right)$ dengan kemampuan lompat jauh (Y)

dengan kategori kuat. Oleh karena itu menolak $H_{0}$ berarti terdapat hubungan.

Tabel 10 Interprestasi Koefisien Korelasi Nilai r

\begin{tabular}{cc}
\hline Tingkat Hubungan & Koefisien Interval \\
\hline Sangat Erat & $0.80-1.000$ \\
Erat & $0.60-0.799$ \\
Cukup Erat & $0.40-0.599$ \\
Kurang & $0.20-0.399$ \\
Sangat Kurang & $0,00-0.199$ \\
\hline
\end{tabular}

Dalam hal ini $r_{\text {hitung }}$ sebesar 0,641 dan $\mathrm{r}_{\text {tabel }}$ sebesar 0,367 hasil hubungan sebesar 5\%. Hipotesis nihil (Ho) tidak diterima sedangkan hipotesis alternatif (Ha) di accept, hasil penelitian menunjukkan adanya hubungan kecepatan saat lari $\left(\mathrm{X}_{1}\right)$ dan daya ledak pada otot tungkai $\left(\mathrm{X}_{2}\right)$ bersamaan kemampuan lompat jauh (Y).

Diketahui nilai koefisien korelasi keseluruhan sebesar antara daya ledak otot tungkai dengan kemampuan dan kecepatan lari adalah 0,641 sedangakan $r_{\text {tabel }}$ sebesar 0,367 hasil hubungan yaitu $5 \%$ ini menyatakan memiliki hubungan daya ledak otot tungkai dengan hasil kemampuan pada lompat jauh gaya jongkok dan kecepatan lari.

\section{SIMPULAN}

Dapat disimpulkan bahwa memiliki hubungan signifikan antara daya ledak otot tungkai terhadap kemampuan lompat jauh gaya jongkok peserta didik kelas VIII Madrasah Tsanawiyah Negeri Ketapang.

1. Hubungan signifikan pada kemampuan lompat jauh dan kecepatan lari peserta didik Madrasah Tsanawiyah Negeri Ketapang. Karena koefisien hubungan dan kemampuan lompat jauh (Y) serta kecepatan saat lari $\left(\mathrm{X}_{1}\right)$ sebesar $\mathrm{r}_{\mathrm{x} 1 \mathrm{y}}=$ $0,410>r_{\text {tabel }}=0,367$ antara pada taraf signifikansi $5 \%$. Dengan telah didapatkannya hasil maka memiliki hubungan. 
2. Pada peserta didik di Madrasah Tsanawiyah Negeri Ketapang Karena koefisien hubungan kemampuan lompat jauh $(\mathrm{Y})$ sebesar $_{\mathrm{rx} 2 \mathrm{y}}=0,626>_{\text {rtabel }}=$ 0,367 dengan daya ledak otot tungkai $\left(\mathrm{X}_{2}\right)$ saat memiliki hubungan 5\%. Dengan telah didapatkannya hasil, maka $\mathrm{X}_{2}$ dan $\mathrm{Y}$ memiliki hubungan yang signifikan.

Pada penelitian terhadap peserta didik Madrasah Tsanawiyah Negeri Ketapang memiliki koefisien hubungan, yang mana terdapat antara kemampuan lompat jauh (Y) sebesar $r_{\text {hitung }}=0,641$ dan $r_{\text {tabel }}$ sebesar $=0,367$ pada taraf signifikansi $5 \%$ pada kecepatan lari $\left(\mathrm{X}_{1}\right)$ serta daya ledak otot tungkai $\left(\mathrm{X}_{2}\right)$ merupakan hasil yang memiliki hubungan secara signifikan. Maka hasil hipotesis hasil hipotesis nihil (Ho) sementara hasi dari hipotesis alternatif $(\mathrm{Ha})$ berhasil dikarenakan adanya suatu hubungan sampai dimana dapat menghasilkan kemampan lompat jauh gaya jongkok. Dalam hal ini hubungan yang signifikan yang dimiliki oleh daya ledak pada otot tungkai dan kecepatan saat lari yang dimiliki peserta didik Madrasah Tsanawiyah Negeri Ketapang.

\section{DAFTAR PUSTAKA}

Arifah, H. L. (2014). Pengaruh Permainan Lompat Terhadap Hasil Belajar Lompat Jauh Gaya Jongkok Dalam Pembelajaran Pendidikan Jasmani, Olahraga Dan Kesehatan (Studi pada Siswa Kelas V SDN Kabuh I Jombang). Jurnal Pendidikan Olahraga Dan Kesehatan, Vol. 2.

Arikunto, S. (2006/2010). Prosedur Penelitian Suatu Pendekatan Praktik. Jakarta: PT Rineka Cipta

Aziz, M. A. (2018). Perbedaan Pengaruh Latihan Pliometrik Dan Kecepatan Lari Terhadap Kemampuan Lompat Jauh Gaya Jongkok. Jurnal Pendidikan Jasmani Dan Olahraga, Vol. 3.

Nur, A. (2019). Pengaruh Latihan Lompat Rintangan terhadap Kemampuan Lompat Jauh Gaya Jongkok pada Siswa Putra SMP Negeri 1 Luwuk. Jurnal Pendidikan Olahraga, Vol. 9.
Riduwan. (2004). Dasar - Dasar Statistika. Bandung : Alfabeta

Sobarna, A. (2020). Meningkatkan keterampilan lompat jauh gaya jongkok siswa SD memalui pembelajaran Kids atletik. Jurnal Pendidikan Dasar Dan Pembelajaran, Vol. 10.

Widiyatmoko, F. A. (2017). Evaluation Of Value Education Implementation In Sport Learning. JPOS (Journal Power Of Sports), Vol. 3. 